$12-2016$

\title{
Case Note: Case of Vasiliauskas v. Lithuania in the European Court of Human Rights
}

Stoyan Panov

University of Freiburg

Follow this and additional works at: https://digitalcommons.usf.edu/gsp

\section{Recommended Citation}

Panov, Stoyan (2016) "Case Note: Case of Vasiliauskas v. Lithuania in the European Court of Human Rights," Genocide Studies and Prevention: An International Journal: Vol. 10: Iss. 3: 81-87.

DOI:

http://doi.org/10.5038/1911-9933.10.3.1456

Available at: https://digitalcommons.usf.edu/gsp/vol10/iss3/8

This Case Study is brought to you for free and open access by the Open Access Journals at Digital Commons @ University of South Florida. It has been accepted for inclusion in Genocide Studies and Prevention: An International Journal by an authorized editor of Digital Commons @ University of South Florida. For more information, please contact digitalcommons@usf.edu. 


\title{
Case Note: Case of Vasiliauskas v. Lithuania in the European Court of Human Rights
}

\author{
Stoyan Panov \\ University of Freiburg \\ Freiburg im Breisgau, Germany
}

\section{Introduction and Facts of the Case}

Lithuania was incorporated in the USSR under the name "the Lithuanian Soviet Socialist Republic" in 1944. In 1949, an all-partisan organization fighting for the independence of Lithuania was formed. From mid-September 1951, Mr. Vasiliauskas had been working as an operation agent of the MGB, the precursor of the KGB, on the territory of the Lithuanian SSR. On January 2, 1953, Mr. Vasiliauskas took part in an operation against two Lithuanian partisans of the Movement of the Struggle for the Freedom of Lithuania, the brothers J.A. and A.A, who were shot and killed in the Šakiai area in Lithuania. After the January 2, 1953 operation, Mr. Vasiliauskas was promoted to a senior operational agent and was awarded and decorated at least 24 times in his 25 -year service in the KGB.

In 2001, Vasiliauskas, along with another co-defendant, were charged with the crime of genocide perpetrated against the pair of Lithuanian partisans as representatives of a political group under Article 71(2) of the Lithuanian Criminal Code. ${ }^{1}$ In 2004, the Trial Court in Lithuania convicted Vasiliauskas for the crime of genocide against political, national and ethnic groups under the newly amended Article 99 of the Criminal Code of 1998; and he was sentenced to six years' imprisonment, suspended on health grounds. On September 21, 2004, the Court of Appeal upheld his conviction and, on February 22, 2005, the Supreme Court of Lithuania followed suit. The Supreme Court found that "the 1998 amendments to the Criminal Code established the elements of the crime of genocide, and included in them acts aimed at physical extermination of some or all of the members of a social or political group. This characteristic of the crime of genocide remained in Article 99 of the Criminal Code." 2

The Grand Chamber of the European Court of Human Rights (ECtHR) was seized of the issue of whether under Article 7(1) of the European Convention on Human Rights (ECHR) there was a sufficiently clear legal basis in the applicable law in 1953 for Vasiliauskas' conviction in Lithuania. In particular, the ECtHR was tasked to examine whether the domestic conviction for genocide matched the offence and could have been foreseen by Vasiliauskas at the time of his participation in the operation of January 2, 1953, which resulted in the deaths of J.A. and A.A. The ECtHR decided in favor of Vasiliauskas by nine to eight votes that there was a violation of Article 7 of the ECHR.

\section{Procedure and Claims of the Parties}

Article 7(1) of the ECHR contains the nullum crimen sine lege principle, namely that "no one shall be held guilty of any criminal offence on account of any act or omission which did not constitute a criminal offence under national or international law at the time when it was committed."

Mr. Vasiliauskas' main argument was that the wide interpretation of the crime of genocide applied by the various court instances in Lithuania had no basis in public international law, in particular his conviction under Article 99 of the Lithuanian Criminal Code. Article 99 of the Lithuanian Criminal Code of 21 April 1998 defines the crime of genocide as "a person who, seeking to physically destroy some or all of the members of any national, ethnic, racial, religious, social or political group, organizes, is in charge of or participates in killing...them...shall be punished by imprisonment for a term of from five to twenty years or by life imprisonment." (emphasis added)

The applicant, Mr. Vasiliauskas, claimed that prosecution for the killing of persons belonging to a political or social group was wider than what the Convention on the Prevention and Punishment of the Crime of Genocide (Genocide Convention) allowed for. The applicant also contended that the genocide clause amended in 1998 was retroactively applied. ${ }^{3}$ Finally, he asserted that Article

\footnotetext{
${ }^{1}$ Case of Vasiliauskas v. Lithuania, European Court of Human Rights Grand Chamber Judgment, October 20, 2015,

Application no. 35343/05, paras. 29 and 52.

${ }^{2}$ Ibid., para. 35.

${ }^{3}$ Ibid., para. 123.
}

Stoyan Panov, "Case Note: Case of Vasiliauskas v. Lithuania in the European Court of Human Rights" Genocide Studies and Prevention 10, 3 (2016): 81-87. @2016 Genocide Studies and Prevention.

http://dx.doi.org/10.5038/1911-9933.10.3.1456 
7(2) of the ECHR is not applicable, as his conviction could not be qualified as genocide and, hence, it could not be qualified as "criminal according to the general principles of law recognized by civilized nations."

The State representatives emphasized the specific nature of the resistance in Lithuania by organized military groups of partisans in the 1950s against the Soviet regime. The State asserted that by 1953 more than 500000 Lithuanians had been affected by the terror politics of the Soviet regime by mass killings, deportations or imprisonments. ${ }^{4}$ The aim of the Soviet regime was "to destroy the former Lithuanian way of life and to replace it by a new Soviet order comprised of persons without nationality or ethnicity (homo sovieticus). ${ }^{5}$ The murders of J.A. and A.A. could not only be regarded as murders of two members of a political group, but also as killings of persons belonging to two protected groups under the Genocide Convention, namely a national and an ethnic group, as the Soviet regime sought "to annihilate the culture, religion, language, politics and identity of the Lithuanian nation," according to the State. ${ }^{6}$ The State claimed that the acts of the applicant constituted the criminal offence of genocide under conventional and customary international law in 1953 and it invoked as evidence UN Resolution 96 (I) of 1946 and the 1948 Genocide Convention to which the USSR was a party in 1953.

\section{The Issue}

Mr. Vasiliauskas' conviction was based on legal provisions that were not in force in 1953 as Lithuania was not an independent state at that time. Therefore, according to the applicant, such domestic provisions were applied retroactively, and the ECtHR had to decide whether there was a violation of Article 7 of the ECHR, unless the Court could find that the applicant's conviction was based upon international law as it stood at the relevant time of the commission of the alleged acts of genocide.

\section{The Court's Assessment}

The ECtHR began the analysis of Article 7 of the ECHR by ascertaining that a criminal offence must be defined in law, which prescribes a penalty, and that the principle must not be extensively construed to the accused's detriment. The offence must be clearly defined in national and/or international law "where the individual can know from the wording of the relevant provision... what acts and omissions will make him criminally liable." ${ }^{\prime 7}$ The principle comprises of two elements-accessibility and foreseeability. The Court defined its task in the particular case as examining "whether there was a contemporaneous legal basis for the applicant's conviction and, in particular, [whether] the result reached by the Lithuanian courts was compatible with Article 7" of the ECHR. ${ }^{8}$

\section{Accessibility}

The ECtHR ruled that the domestic convictions of Mr. Vasiliauskas were based on retroactive applicability of Article 99 of the Criminal Code as the legal provision was not in force in 1953. Hence, this would constitute a violation under Article 7 of the ECHR, unless the international law at the time of the commission of the act in 1953 allowed for such conviction. ${ }^{9}$ The ECtHR examined the relevant international agreements to which the USSR was a party in 1953. The USSR signed the Genocide Convention on December 16, 1949 and the Convention came into force on January 12, 1951. Therefore, the Court did not have trouble in finding that the crime of genocide was clearly recognized as an international crime in 1953, and the prohibition of genocide was "sufficiently accessible to the applicant."10

\footnotetext{
${ }^{4}$ Ibid., para. 133.

${ }^{5}$ Ibid., para. 135 .

${ }^{6}$ Ibid., para. 142 .

${ }^{7}$ Ibid., para. 154.

${ }^{8}$ Ibid., para. 161.

${ }^{9}$ Ibid., para. 166.

${ }^{10}$ Ibid., para. 168.
} 
Foreseeability and "In Part" Interpretation

The crux of the case is whether it was foreseeable under international law in 1953 that the act for which the applicant was convicted could be qualified as genocide, and whether J.A. and A.A., with their prominent positions within the Lithuanian partisan movement, could fall under the protection of the national and ethnic groups. The ECtHR reiterated the possibility for wider and narrower interpretation in international and national law of the crime of genocide. The ultimate test in deciding what interpretation is applicable is the foreseeability element, as established by the Court in the Jorgić case, for "the scope of the concept of foreseeability depends to a considerable degree on the content of the instrument in issue, the field it is designed to cover and the number and status of those to whom it is addressed."11 The ECtHR also cautioned that there is a particular obligation on persons in official capacity, such as Vasiliauskas, to proceed with a high degree of caution when pursuing their occupation.

The ECtHR affirmed that it is legitimate and foreseeable for a successor State, such as Lithuania, to initiate criminal proceedings against individuals who have committed crimes under the former regime and "successor courts cannot be criticised for applying and interpreting the legal provisions in force at the material time during the former regime, but in the light of the principles governing a State subject to the rule of law and having regard to the core principles on which the Convention system is built." 12 This is particularly exigent when the case concerns the right to life, "a supreme value in the Convention and international hierarchy of human rights and which right Contracting Parties have a primary Convention obligation to protect along with the obligation on the State to prosecute war crimes." 13 The Grand Chamber unsurprisingly reached the conclusion that domestic courts cannot convict the accused on retroactively applied broader interpretation of the crime of genocide passed later in time; although, domestic authorities are allowed to legislate broader scope of genocide in general. ${ }^{14}$ The same reasoning regarding retroactivity was also provided by the Lithuanian Constitutional Court, which in March 2014 ruled that the retroactive prosecution for genocide of a political or social group, when the crime was committed prior to the amendments of the Lithuanian Criminal Code in 1998, was unconstitutional.

Then the ECtHR examined the definition of the crime of genocide as it stood in 1953. Article II of the Genocide Convention covers four protected groups of persons: national, ethnical, racial or religious, and does not explicitly refer to social or political groups. The ECtHR looked at the drafting history of the Convention by citing the ICJ's Bosnia and Herzegovina v. Serbia and Montenegro case on the inclusion of the closed list of four specific groups. The ECtHR also invoked the Statutes of the ICTY, the ICTR and the ICC to conclude that "genocide is defined as acts committed to destroy a national, ethnical, racial or religious group, without reference to political groups."15 The crime of genocide was clearly recognized under international law in 1953 as evidenced by the 1946 UNGA Resolution 96(I), the 1948 Genocide Convention which was signed by the USSR on December 16, 1949 and came into force with the twentieth ratification on January 12, 1951, along with the ICJ's 1951 Advisory Opinion which emphasized that "the principles underlying the Genocide Convention are principles which are recognized by civilized nations as binding on States, even without any conventional obligation."16 The ECtHR found that "at the relevant time the applicant, even with the assistance of a lawyer, could have foreseen that the killing of the Lithuanian partisans could constitute the offence of genocide of Lithuanian nationals or of ethnic Lithuanians." 17 Nonetheless, the ECtHR deviated with the finding of the Lithuanian courts that the Lithuanian partisans constituted a significant part of the national or ethnic group in 1953, thus excluding J.A. and A.A. of the protection of Article II of the Genocide Convention.

\footnotetext{
${ }^{11}$ Ibid., para. 157.

${ }^{12}$ Case of Kononov v. Latvia, European Court of Human Rights Grand Chamber Judgment, May 17, 2010, App. No. 36376/04, para. 241.

${ }^{13}$ Ibid.

${ }^{14}$ Vasiliauskas v. Lithuania, GC Judgment, para. 181.

${ }^{15}$ Ibid., para. 170.

${ }^{16}$ Ibid., para. 80 .

${ }^{17}$ Ibid., para. 181.
} 
The main issue was whether the two killings of J.A. and A.A. could be considered to fall into the protected national and/or ethnic group along with belonging to a political group. The ECtHR focused on what is meant by the term "acts committed with intent to destroy,...in part, a national, ethnical, racial or religious group, as such" in the elements of the crime of genocide under Article II of the Genocide Convention. The majority recalibrated its focus to finding whether before a conviction the demanding proof of specific intent, dolus specialis, is coupled with showing that the targeted group for destruction in its entirety or in substantial part was met. Based on the jurisprudence of the ICTY, ICTR, and ICJ, the ECtHR found that in 1953 it was foreseeable that the term "in part" contained a substantiality requirement, namely a numerical size of the targeted part of the group along with the prominence of the targeted individuals within the protected group. Nonetheless, the ECtHR reached the conclusion that the principles and interpretation in the cited jurisprudence as regards the prominence part could not have been foreseen by the applicant in the particular case to be included in the "in part" term in $1953 .{ }^{18}$ However, could the murders of the Lithuanian partisans as a significant part of the nation pass the threshold of the impact that their extermination would have on the survival of the national or ethnic group of Lithuanians as a whole?

There is no doubt that genocide could be discerned in the annihilation of a vast number of members of the protected group(s) coupled with the dolus specialis of the perpetrator. Moreover, the specific genocidal intent could consist of "the desired destruction of a more limited number of persons selected for the impact that their disappearance would have upon the survival of a group as such." 19 The intention to destroy the group "selectively" is based on the notion that the numeric size of the targeted part of the group should not be the end of the inquiry in order to determine the substantive requirement, but "in addition to the numeric size of the targeted portion, its prominence within the group can be a useful consideration." ${ }^{20}$ The intention to destroy at least a substantial part of a particular group means "a reasonably substantial" rather than a purely numerically-based "reasonably significant" concept. In this manner, if the evidence of an intention to destroy a reasonably substantial number relative to the total population of the group is not met, then the specific intent of the perpetrator "may yet be established by evidence of an intention to destroy a significant section of the group, such as its leadership." ${ }^{21}$ In other words, if the quantitative criterion is not met, the intention to destroy "in part" may be established by the qualitative criterion of the significance of the targeted section of the group, such as the leadership "who by reason of their special qualities of leadership within the group as a whole, are of such importance that their victimization...would impact upon the survival of the group, as such."22

Such interpretation for taking into account the prominence of the targeted persons within the group as a whole was also applied by the ICJ's 2015 Croatia v. Serbia decision. ${ }^{23}$ Another example is the killing of three Bosnian Muslim leaders in Žepa which "was a case of deliberate destruction of a limited number of persons selected for the impact that their disappearance would have on the survival of the group as such," thus emphasizing to all other members of the group their collective vulnerability and defenselessness. ${ }^{24}$

The ECtHR accepted the argument of the applicant that the purpose of the MGB's policies in Lithuania were aimed at the extermination of the partisans exclusively as "a separate and clearly identifiable group, characterized by its armed resistance to Soviet power." ${ }^{25}$ In this manner the ECtHR rejected the finding of the domestic courts that the victims came within the definition of genocide as part of a protected group by analogy as such interpretation is to the applicant's

\footnotetext{
${ }^{18}$ Ibid., para. 177.

${ }^{19}$ Prosecutor v. Jelisić, Trial Chamber Judgment, December 14, 1999, IT-95-10, paras. 80 and 82.

${ }^{20}$ Prosecutor v. Krstić, Appeals Chamber Judgment, April 19, 2004, IT-98-33-A, para. 12.

${ }^{21}$ Prosecutor v. Sikirica, Judgment on the Defence Motion to Acquit, September 2, 2001, IT-95-8, paras. 65 and 76.

${ }^{22}$ Ibid., para. 77.

${ }^{23}$ Application of the Convention on the Prevention and Punishment of the Crime of Genocide (Croatia v. Serbia), International Court of Justice Judgment, February 3, 2015, para. 142.

${ }^{24}$ See Prosecutor v. Tolimir, Trial Chamber Judgment, December 12, 2012, IT-05-88/02.

${ }^{25}$ Vasiliauskas v. Lithuania, GC Judgment, para. 182.
} 
detriment and the conviction would be rendered unforeseeable. Hence, the positions of J.A. and A.A. were rejected to be prominent enough to fall under the protection of Article II of the Genocide Convention.

Article 7 of the ECHR was interpreted differently in a joint dissenting opinion of Judges Villiger, Power-Forde, Pinto de Albuquerque and Kuris (Joint Dissenting Opinion). The four dissenting judges offered a detailed overview of the necessity to incorporate the assessment of the protected group(s) in light of the particular political, social and cultural context. ${ }^{26}$ The protected group is to be assessed on a case-by-case basis by taking into account the objective particulars of the social or historical context along with the subject perceptions of the perpetrator. ${ }^{27}$ The Lithuanian courts found that the sole existence of the partisans was the protection of the Lithuanian nation against the Soviet regime, which aimed at destroying its whole identity and, as such, the extermination policies of the Soviet authorities were targeting the nationality-ethnicity aspect. ${ }^{28}$ It should also be recalled that the purpose of the policies of the Soviet authorities centered "on the intent to destroy the fabric of a society through the elimination of its leadership, when accompanied by other heinous acts, such as mass deportations, could give a strong indication of genocide." 29

The four dissenting judges noted that the partisans could not have survived for more than 10 years as a national movement without the support of the Lithuanian people, and that J.A. and A.A. were targeted as ethnic Lithuanian partisans due to their prominence in society. The partisan movement consisted of members who were "simultaneously a significant and emblematic part of the national group and whose very purpose was the protection of the Lithuanian nation from destruction by the Soviet regime and that their killing was, therefore, an act of genocide." 30 The Lithuanian partisans may be considered a significant part of the national group because of their prominence and emblematic character as a targeted part of the specifically protected group, the four dissenting judges concluded.$^{31}$ The partisans were targeted as a distinct, significant part of a group to be eliminated rather than as mere individuals within the group. Otherwise, why would the MGB/KGB documents not show any attempt to capture or bring the suspects to court? ${ }^{32}$ Judge Power-Forde concluded in her separate dissenting opinion that the approach of the majority in the case was "excessively formalistic and rather blinkered approach of viewing the partisans solely through the lens of a 'political group' and of ending its analysis there." ${ }^{33}$

The foreseeability of the existence of the crime of genocide could include circumstantial evidence to show the specific intent "such as the physical targeting of the group or of their property; the use of derogatory language towards members of the targeted group; the weapons employed and the extent of bodily injury; the methodological way of planning, the systematic manner of killing." ${ }^{\prime 34}$ It is important to note that the factual analysis of the Lithuanian Courts was not arbitrary but based on the archival documents presented before the domestic instances and the acknowledgement of the Russian Federation in 1991 that the peoples including the Lithuanians were subjected to repression including genocide under the Soviet era. ${ }^{35}$ The Dissenting Opinion also invokes the number of the 20,000 Lithuanian partisans who were killed between 1944 and 1953. The MGB issued clear instruction in 1953 for extermination as evidenced by the minutes of the MGB from March 1953, urging that "bandits and nationalist underground should be eradicated" and that "[the MGB unit's] goal was to exterminate as quickly and possible the bandits, those who help them and

\footnotetext{
${ }^{26}$ Prosecutor v. Rutaganda, Trial Chamber Judgment, December 6, 1999, ICTR-96-3, para. 56.

${ }^{27}$ Prosecutor v Semanza, Trial Chamber Judgment, May 15, 2003, ICTR-97-20, para. 317.

${ }^{28}$ Vasiliauskas v. Lithuania, GC Judgment, para. 36.

${ }^{29}$ Vasiliauskas v. Lithuania, Joint Dissenting Opinion, para. 19.

${ }^{30}$ Ibid., para. 16.

${ }^{31}$ Ibid., para. 24

${ }^{32}$ Vasiliauskas v. Lithuania, Judge Ziemele Separate Dissenting Opinion, para. 25.

${ }^{33}$ Vasiliauskas v. Lithuania, Judge Power-Forde Separate Dissenting Opinion.

${ }^{34}$ Prosecutor v. Kamuhanda, Trial Chamber Judgment, January 22, 2004, ICTR-99-54A, para. 625.

${ }^{35}$ Vasiliauskas v. Lithuania, GC Judgment, para. 74, and Vasiliauskas v. Lithuania, Joint Dissenting Opinion, para. 4.
} 
their contacts." ${ }^{36}$ It is sufficiently clear that the criminal plan was to exterminate any vestige of the identification with the national and ethnic belonging of the Lithuanians. The dissenting judges disagree with the finding of the majority that the applicant could not have known that he risked being charged with and eventually convicted of genocide in light of his high position in the MGB at the time of the operation. ${ }^{37}$

Had Mr. Vasiliauskas sought legal advice as a high operational agent of the MGB whose task was the extermination of the most resistant part of the Lithuanian nation, "it is likely that he would have been advised that what he was doing bore the essential characteristics of the crime of genocide as it stood under international law at the time." ${ }^{38}$ The atmosphere of complete impunity that the MGB agents enjoyed in their operations, evidenced by the lack of any prosecution even under the acting criminal code of the Russian SFSR for the deprivation of life in the particular case, does not in any way affect the applicability and binding force of international law and the prohibition of genocide on the territory of the USSR. ${ }^{39}$ Coupled with mass deportations, imprisonment and repressions against the partisans' families, the cluster of acts against the protected group of the Lithuanian nation and ethnicity should be considered in its entirety in order to appropriately interpret the provisions in the Genocide Convention. ${ }^{40}$ Judge Ziemele in a Separate Dissenting Opinion provided elaborate analysis of the historical context of the struggle of the Lithuanian national partisans against the Soviet authorities by concluding that "the extermination of Lithuanian nationalism was necessary to achieve the subjugation of the Lithuanian people to the Soviet regime and its ideology." 41

In regards to customary international law, the ECtHR accepted that the scope of the crime of genocide could be different from the conventional provisions, although opinions are divided on this subject matter. Special attention was paid to the language of the 1946 UNGA Resolution 96(1) which called to protect "racial, religious, political groups and other groups" from genocide (emphasis added). The ECtHR provided three references to academic articles, which offer seemingly conflicting views on whether the customary prohibition of genocide included political or other groups in 1953. The Court sweepingly concluded that "there is no sufficiently strong basis for finding that customary international law as it stood in 1953 included 'political groups' among those falling within the definition of genocide" as "the scope of the codified definition of genocide remained narrower in the 1948 Convention and was retained in all subsequent international law instruments." 42 Such glossing over customary law is problematic as the ECtHR did not look in detail at the constitutive elements of customary law, namely state practice and opinio juris. The fact that the subsequent conventions codified a different scope of the protection does not necessarily mean that the customary law prohibition must have been identical in 1953. Custom and treaties are two separate sources of international law and the norms continue to co-exist and retain their separate existences, even if the relevant clauses are identical in content as stated in ICJ's Military and Paramilitary Activities in Nicaragua case. The ECtHR should have looked into the state practice as in domestic judicial decisions during the relevant period from 1946 until 1953, as well as pronouncements of state officials.

By just referring to a few law articles or books, one could not fully entertain the notion that the ECtHR has effectively served its function as a regional judicial body to find evidence whether customary law, in regards to the scope of the prohibition of genocide and the corresponding criminalization, were narrower or wider in 1953 in comparison to Article II of the Genocide Convention. For example, the ECtHR could have examined the Eichmann case of 1962, where the Supreme Court of Israel refers directly to UNGA Resolution 96(I) as evidence that the crime of

\footnotetext{
${ }^{36}$ Vasiliauskas v. Lithuania, GC Judgment, para. 18.

${ }^{37}$ Vasiliauskas v. Lithuania, Joint Dissenting Opinion, paras. 29 and 30.

${ }^{38}$ Ibid., para. 30.

${ }^{39}$ Vasiliauskas v. Lithuania, GC Judgment, paras. 71 and 72.

${ }^{40}$ Vasiliauskas v. Lithuania, Joint Dissenting Opinion, para. 26.

${ }^{41}$ Vasiliauskas v. Lithuania, Ziemele Dissenting Opinion, para. 13.

${ }^{42}$ Vasiliauskas v. Lithuania, GC Judgment, para. 175.
} 
genocide was recognized during and after the Second World War. Although there are contemporary instances of domestic jurisdictions enlarging the scope of the protected group to include social and political groups, the ECtHR could have elaborated more on the issue as regards the early period of the prohibition of genocide in late 1940s and early 1950s. ${ }^{43}$ Hence, it is difficult to discern how the majority in the particular case reached an opinion different from the established principle that there is no retroactive application of the substantive law when the conviction in the domestic courts in part is based on the rules existing at the time of the commission of the act. ${ }^{44}$

The ECtHR concluded with the non-applicability of Article 7(2) of the ECHR by examining if the applicant's acts at the relevant time were criminal according to the general principles of law recognized by civilized nations. The ECtHR recalled the original, exceptional purpose of Article $7(2)$ as being interlinked and interpreted in a concordant manner with Article 7(1) as laid down in the Tess $v$. Latvia case. The ECtHR rejected the argument that the rule of non-retroactivity does not apply if the act was criminal under Article 7(2) as Article 7(1) contains the general rule of the prohibition of retroactivity and Article 7(2) "is only a contextual clarification of the liability limb of that rule." ${ }^{45}$ Hence, if the applicant's conviction could not be justified under Article 7(1), it cannot be justified under Article 7(2) of the ECHR.

${ }^{43}$ Vasiliauskas v. Lithuania, GC Judgment, para. 58.

${ }^{44}$ Vasiliauskas v. Lithuania, Ziemele Dissenting Opinion, para. 20.

${ }^{45}$ Case of Maktouf and Damjanović v. Bosnia and Herzegovina, European Court of Human Rights Grand Chamber Judgment, July 18, 2013, App. Nos. 2312/08 and 34179/08, para. 72. 